\title{
'You're gunna get wacked!' The political economy of the Australian carbon and mining tax reforms
}

Associate Professor Justin Dabner, Law School, James Cook University, Cairns, Australia; Adjunct research fellow in Business Law and Taxation, Faculty of Business and Economics, Monash University, Australia

Visiting Professor, Centre for Pacific and American Studies, Tokyo University

Justin.Dabner@jcu.edu.au 


\title{
'You're gunna get wacked!' The political economy of the Australian carbon and mining tax reforms
}

\begin{abstract}
For most developed nations the last five years have ushered in difficult economic times. Not though for resource rich Australia which has sustained high economic growth courtesy of the unquenchable thirst of China for its minerals.

However the benefits of the mining boom have not been evenly felt, giving rise to the description "two speed economy". In fact, the success of the mining industry has contributed to a dampening effect on some other sectors of the economy that have struggled in response to inflationary pressures, higher interest rates, skill shortages and the high Australian dollar, all a bi-product of the resources boom. Furthermore, peculiarities in the way that State mining royalties are calculated have not seen any substantial increase in Government revenues compared with soaring mining profits.

Under the mantra "spreading the benefits of the boom" the Commonwealth Government stepped in to address this perceived structural flaw in the economy by proposing an additional tax on mining resource rents or "super profits" from 1 July 2012. In an extremely effective anti-tax campaign the industry was able to have the tax threat all but removed with the aid of the very community for whose benefit it had been conceived. In the process the industry succeeded in having the Prime Minister, who proposed the tax, dismissed by his own party and deceived the new leadership team into agreeing to a regime that in its first quarter of operation was not able to raise one cent of tax.
\end{abstract}

At the same time the Government introduced an carbon tax / emissions trading scheme ("ETS") putting it at the cutting edge of climate change response using fiscal measures. However the path to the introduction of this regime was similarly not easy. Whilst Australia had been active in negotiating the 1997 Kyoto Protocol, during the subsequent decade the Liberal coalition Government refused to embrace a price on carbon. With the election of a Labor Government in 2007 the Kyoto Protocol was promptly ratified and an ETS proposed. However it met neither the expectations of environmentalists nor industry and in 2010 was shelved. Although it seemed that the impetus had been lost, with the toppling of a Prime Minister later that year and a Federal election resulting in Labor forming a coalition with the Greens, momentum again swung in favour of an ETS.

There may be political economy lessons for the rest of the world in both how the mining tax was blunted and also how the ETS was designed and implemented in Australia. 


\section{'You're gunna get wacked!' The political economy of the Australian carbon and mining tax reforms}

\section{Introduction}

On 1 July 2012 two significant new tax regimes commenced in Australia: a resource rents or mining tax and a carbon tax / emissions trading scheme ("ETS"). Both of these regimes have been highly controversial and, indeed, experimental. Policy makers around the globe have watched with interest both the political economy leading to their introduction and their design features. It can be expected that the success or otherwise of their operation will be monitored.

This paper seeks to outline the political economy surrounding their introduction. The evidence is that the Government may have induced or even deceived into introducing a mining tax that will be quite ineffective. Similar concerns might be levied in relation to the carbon tax / ETS. In any event, the future of both taxes is not assured.

\section{The Mining Tax}

\section{A fair return for the community's assets}

On any economic measure the last decade has been a boom time for the Australian economy. Whilst the rest of the developed World, in particular Europe and the United States, has faltered under the stresses of the global financial crisis the Australian economy has surged on. A resources boom, driven by an insatiable thirst for raw materials in Asia, particularly China, ensured that the average growth rate in Australia remained at or above 3\%. Low unemployment rates and Government surpluses are the envy of the World. ${ }^{1}$

But hidden behind the macroeconomic statistics is a story of an uneven distribution of wealth. Whilst the mine owners have become amongst the wealthiest people in the World and ordinary Australians able to relocate to the remote mine sites draw extraordinarily high wages, those working outside the resources sector are not enjoying the spoils. This has given rise to the term "two-speed economy" to describe the gulf between that part of the economy benefitting from the mining boom and the rest. ${ }^{2}$ At the

\footnotetext{
1 Jonathan Kearns and Philip Lowe, "Australia's Prosperous 2000s: Housing and the Mining Boom" Reserve Bank of Australia, Research Discussion Paper RDP2011-07, December 2011, available at http://www.rba.gov.au/publications/rdp/2011/pdf/rdp2011-07.pdf.

${ }^{2}$ When taking into account regional areas and other industries suffering from the high exchange rates, such as the manufacturing sector, the expression "3 speed economy" might be more apt.
} 
same time the Gini co-efficient, which measures the extent of the distribution of wealth in a country, is showing a disturbing trend away from the egalitarian society that Australia has traditionally claimed to be. ${ }^{3}$

Not only has it emerged that the benefits of the boom (as the mantra has become) were not being equally enjoyed but, in fact, the success of the resources industry was actually making the environment in which other sectors of the economy were operating more difficult. The exit of skilled employees to the mining sites in pursuit of the huge wages saw a glut in the other regions resulting in construction delays and pressure on wages and subcontractor hourly rates. There were also complaints that the mining industry was not doing its share of training with the suggestion that other industries were subsidizing the training of staff, who, once they had their ticket, headed for the mines.

Furthermore, the vast amounts of money being invested in mining infrastructure has had an inflationary pressure on goods and services and, most significantly, kept the interest rates at a higher level. This has added to the pressures on the exchange rate which saw the Australian dollar climb well past parity with the greenback and stay there. It was this later aspect that was particularly hurting other sectors, especially export focused industries such as tourism and manufacturing.

The nature of Australia's land tenure system is that most of the mineral and oil wealth is owned by the Crown, primarily the State Governments. ${ }^{4}$ Those States lucky enough to be the source of this wealth traditionally charge a royalty for its extraction. Whilst this creates inequalities between the States, here the Federal Government has a role to play in its allocation of tax revenues to ensure a relatively uniform standard of living across the Commonwealth. Whilst the precise basis for the calculation of the royalties due to the States differs these measures were determined by the Commonwealth Government to be inadequate in trapping for the community a fair share of the mining wealth that was being generated. The States professed reluctance to change their royalty models as they were concerned at the competitive advantage that might provide other jurisdictions resulting in a loss of investment and, in some cases, they had entered into agreements with the mining companies that made adjustments difficult. So it was that the Commonwealth Government pressed ahead with a proposal for an additional tax on the "super profits" of the mining industry.

The diagram below illustrates how the return to the States effectively tracked as a relatively constant percentage of the profits from mining, up until the mid-2000s. Then

\footnotetext{
${ }^{3}$ OECD, Divided we stand. Why inequality keeps rising, 5 November 2011 available at http://www.oecdilibrary.org/social-issues-migration-health/the-causes-of-growing-inequalities-in-oecdcountries 9789264119536-en.

${ }^{4}$ A good summary of how this came to be can be found at http://en.wikipedia.org/wiki/Australian mining law.
} 
an increasing gulf began to emerge as the mining companies started generating much higher profits due to an increase in World resources prices that did not factor into any significant increase in the royalties. The concern that the Australian population was missing out on a fair share of this mining boom was heightened as foreign interests, especially Chinese companies, began to acquire greater interests in the mining companies with profits increasingly flowing offshore.

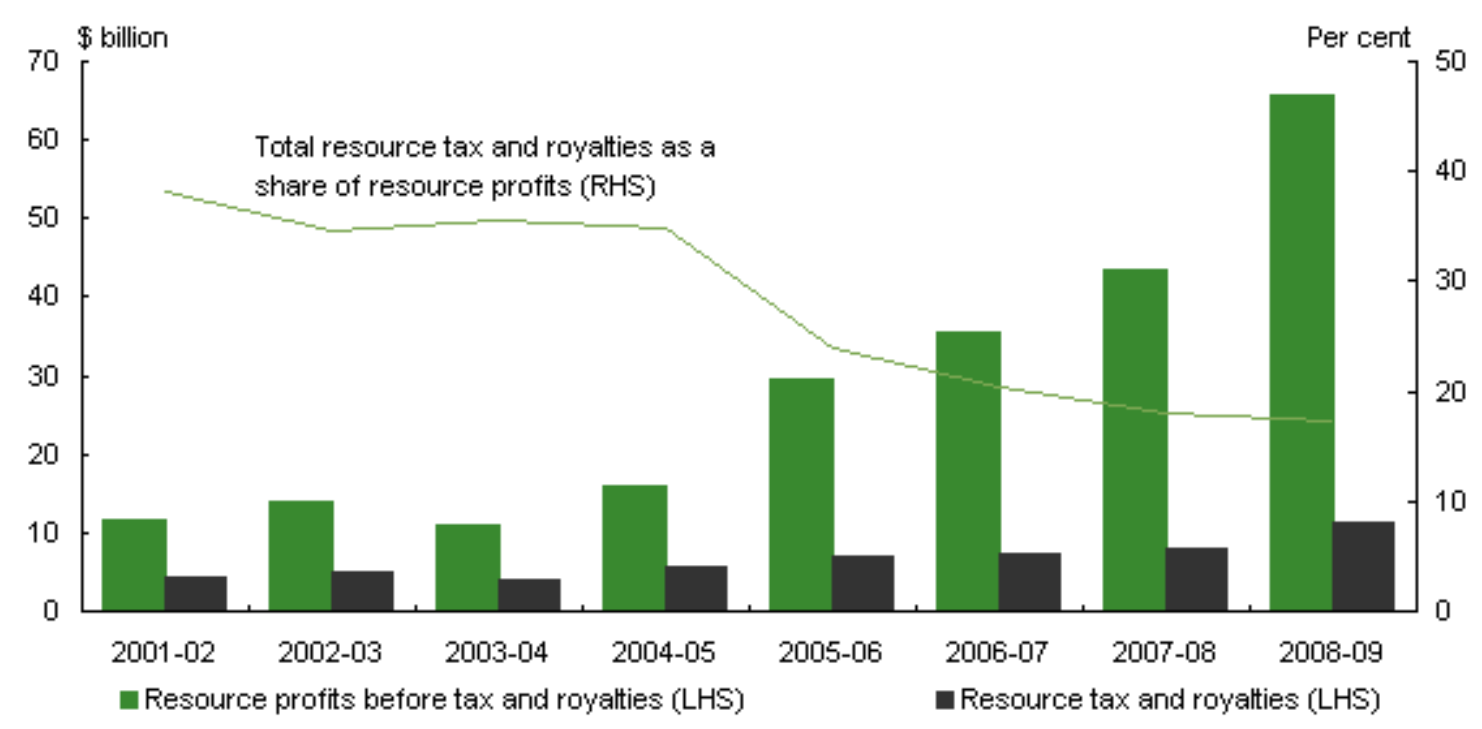

Source: Australia's future tax system, Commonwealth of Australia 2010, available at http://www.taxreview.treasury.gov.au/content/Content.aspx?doc=html/pubs reports.htm

\section{The response to the tax}

Immediately upon the announcement the mining industry went on the attack. ${ }^{5}$ In particular it financed an advertising campaign that promoted the benefits of the mining industry for the ordinary Australian and how the tax threatened its well being. The industry focused on the emotive side, what the industry had done for the country and how employment would be dramatically reduced (particularly impacting on regional areas) if the tax was imposed. In a very effective "You're gunna get wacked" line of commercials the industry's interests were assimilated to those of the common person. ${ }^{6}$ There were also scenes of rallies with the (billionaire) mine owners agitating the workers against the tax leading with the slogan "Axe the tax". The tax was argued to generate

\footnotetext{
${ }^{5}$ For example see: Mathew Murphy, "Miners reject the resource super profits tax grab", The Age (3 May 2010) available at http://www.theage.com.au/business/miners-reject-the-resource-super-profits-tax-grab20100502-u1 ev.html (last visited 26 December 2012).

6 http://www.youtube.com/watch?v=qs7qE2FQLxw.

7 Paige Taylor, "Resource magnates rally to their protests against the tax", The Australian (10 June 2010) available at http://www.theaustralian.com.au/politics/resource-magnates-rally-to-their-protest-againsttax/story-e6frgczf-1225877654062 (last visited 26 December 2012).
} 
sovereign risk that would see mining investment flow to other countries and existing operations scaled back or moth balled. ${ }^{8}$

The campaign was extraordinarily successful resulting in a plunge in the Government's approval ratings. ${ }^{9}$ The poor handling of both this proposal and that of the emissions trading scheme ${ }^{10}$ were attributed to Prime Minister Rudd who was subsequently deposed in late June 2010. ${ }^{11}$

By 2 July 2010 his successor, Julia Gillard, had met with and negotiated significant compromises with three select multinational mining companies (BHP, Rio Tinto and Xstrata). A new Minerals Resource Rent Tax ("MRRT") was proposed ${ }^{12}$ and subsequently referred to a Policy Transition Group ("PTG") to facilitate transition to draft legislation. In October 2010 an issues paper was released with details of the MRRT and of an extension to the PRRT.$^{13}$ Following a series of consultation forums a report was put to the Government ${ }^{14}$ which on 24 March 2011 announced its acceptance of all the PTG's recommendations. Within a year the Mineral Resources Rent Tax (MRRT) Bill 2011 had passed both Houses of Parliament.

Naturally this considerable watering down of the tax was accompanied with a reduction in forward estimates of revenue to be raised down from $\$ 12$ billion over its first two years of operation to $\$ 10.5$ billion. As these estimates factored in expected increases in

${ }^{8}$ Meanwhile the Government's campaign focused on a professor explaining the details of the (complicated) tax to his students.

9 Phillip Coorey, "Labor faces wipeout", Sydney Morning Herald (7 June 2010) available at http://www.smh.com.au/national/labor-faces-wipeout-20100606-xn7v.html (last visited 26 December 2012).

${ }^{10}$ The Carbon pollution reduction scheme: issued first as an exposure draft for public consultation on 10 March 2009, then as a Bill on 14 May 2009 (see

http://parlinfo.aph.gov.au/parllnfo/search/display/display.w3p;query=ld:legislation/billhome/R4127) which, following its failure to pass the Senate, was reintroduced in 2010 but subsequently lapsed upon Parliament rising for the calling of a general election (see

http://parlinfo.aph.gov.au/parllnfo/search/display/display.w3p;query=ld:legislation/billhome/R4281).

${ }_{11}$ The more remarkable given that a mere year earlier he had been one of the most popular Prime Minister in Australian history and had managed to cleverly navigate the economy clear of the global financial crisis engulfing the rest of the developed World: second in ranking with a popularity rating of $74 \%$ : see "The Rudd Supremacy" (March 30, 2009) available at

http://www.brisbanetimes.com.au/national/the-rudd-supremacy-20090330-9g6s.html $\quad$ last visited 6 November 2012).

${ }_{12} \mathrm{~J}$. Gillard, W. Swan and M. Ferguson, "Breakthrough agreement with industry on improvements to resources taxation", Canberra press release, 2 July 2010 reported at http://www.theage.com.au/business/gillard-cuts-mining-tax-deal-20100702-zr62.html.

${ }^{13}$ Policy Transition Group, Issues Paper: Technical design of the minerals resource rent tax transitioning existing petroleum projects to the petroleum resource rent tax and policies to promote exploration expenditure, Canberra, Australian Government, released I October 2010.

${ }_{14}$ Policy Transition Group, Report to the Government: new resource taxation arrangements, Canberra, Australian Government, released 21 December 2010. 
revenue due to commodity price rises of $\$ 6$ billion, the actual reduction in revenues was $\$ 7.5$ billion. $^{15}$

\section{The reality}

Whilst the new leadership in the Government were still crowing about their success there was much conjecture following the issue of the amended forward estimates whether the watered down MRRT would actually raise the amounts foreshadowed by the Government. There was a suspicion fuelled by the Opposition that the Government had overly compromised its tax. ${ }^{16}$

This was confirmed in early October 2012 when the first installment period for the payment of the tax passed without any payment being due. ${ }^{17}$ The reality then struck some in the Parliament that in negotiating a hastily agreed compromise with industry the Government may have been duped. However the Government was in an embarrassing position. Rather than admit to its own ineptitude it stuck to the story being spun by the industry that mining profits were down due to a fall in commodity prices and the high Australian dollar. At the same time it clung to its forecasts that the billions of dollars of tax revenues would begin flowing in the future.

Subsequently in mid-December the Government was forced into an embarrassing admission that expected returns needed to be revised down further with the result that the Government's much vaulted return to a surplus in 2013 would not occur. ${ }^{18}$

The story of how the Commonwealth Government has seemingly been deceived by the mining companies is a vexed and complicated one. It needs to be told against the background of a dramatic toppling of a once very popular Prime Minister by his loyal Deputy and Treasurer. The explanation for the coup was put that the autocratic nature

\footnotetext{
${ }^{15}$ See the Senate Standing Committee on Economics, Answers to Questions on Notice, Treasury Portfolio, Additional Estimates 23 - 24 February 2011, Question: AET 137, Topic: Compare RSPT and the MRRT, Hansard Page: E 25 - E 26 available at

http://www.aph.gov.au/Parliamentary Business/Committees/Senate Committees (last visited 26 December 2012).

${ }^{16}$ This did not stop continued promises by the leader of the Opposition to repeal the tax if they came to power leading to disagreement with some in the industry who, content with what they had negotiated, would rather see the watered down tax remain than risk stimulating the whole debate again. In any event, repealing the tax might not be that straight forward, especially due to the expenditure programs connected to it: Debbie Guest, "Let Tony Abbott repeal mining tax, says new WA Labor leader Mark McGowan", The Australian (20 January 2012) available at http://www.theaustralian.com.au/nationalaffairs/let-tony-abbott-repeal-mining-tax-says-new-wa-labor-leader-mark-mcgowan/story-fn59niix1226248886046 (last visited 26 December 2012).

${ }^{17}$ Mining tax fails to raise any revenue in first three months", News Limited Network (25 October 2012) available at http://www.news.com.au/business/companies/mining-tax-fails-to-raise-any-revenue-in-firstthree-months/story-fnda1bsz-1226502856657 (last visited 24 December 2012).

${ }^{18}$ Ben Packham, "'Hugh whack' to revenue means that budget surplus is now unlikely: Wayne Swan", The Australian (20 December 2012) available at http://www.theaustralian.com.au/nationalaffairs/revenue-slide-in-2012-13-makes-labors-surplus-task-harder/story-fn59niix-1226541057969 (last visited 26 December 2012).
} 
of the Prime Minister's handling of the introduction of the tax had polarized the nation and a much more conciliatory approach was needed. Hence his assassins went into negotiations with the mining companies desperate to broker a compromise and, thereby, validate their bloody treachery. It appears that the mining companies may have sensed their position of strength.

The main argument being used by the miners was that the tax would drive investment offshore. This always had a hollow ring to it as the complaints that Australia somehow represented too much sovereign risk with the imposition of this new tax had to be viewed in the context of the alternative sites for investment, mainly in Africa, hardly the bastion of the rule of law. In fact the Australian mining tax was to set a precedent that has since seen such taxes implemented all over the World. The nationalization of mining rights is now viewed as the greatest issue facing the mining industry. ${ }^{19}$

In any event, the very notion of a Government being required to negotiate with the entities on which it is to impose a tax and they to have the ability to substantially change the Government's position is a questionable proposition. Traditionally, dissatisfaction with Government decisions is voiced at the ballot box not in closed door negotiations whilst they are being made. The mantra of transparency and consultation on tax law changes had become very strong in Australia over the proceeding decade. Successive governments had fine tuned the consultation process in response to criticism of having failed to listen resulting in impractical and compliance heavy legislation. However with the resource rent tax it is arguable that discussions went further than consultation on fine tuning the legislation so that the Government's policy could be efficiently given effect to, to actually negotiating with Government as to what its policy should be.

A further concern is the limited nature of the initial closed door discussions, just three large mining companies. There has been considerable complaint from junior miners to the effect that their exclusion from these discussions resulted in a regime that prejudiced their interests vis-à-vis the big three. The suggestion is that the big three were able to negotiate a regime that gave them a competitive advantage. The juniors are particularly critical of the removal of the exploration rebate and the introduction of an election to allow the market value of pre-1 May 2010 assets to be selected as their starting base for deduction purposes. ${ }^{20}$ It is argued that the former measure would have

\footnotetext{
${ }^{19}$ Stan Correy, "Australia leading global charge on mining returns" $A B C$ News (4 August 2012) available at http://www.abc.net.au/news/2012-08-04/australia-leads-global-charge-on-mining-returns/4176752 (last visited 24 December 2012).

20 The denial of a deduction for financing costs also arguably hurts the juniors more: see Elizabeth Knight, "Forrest quite right to fight a mine tax that bows to the big boys", The Age (16 June 2011) available at http://www.smh.com.au/business/forrest-is-quite-right-to-fight-a-mine-tax-that-bows-to-the-big-boys20110615-1g3v1.html (last visited 24 December 2012) and Katherine French, "Small miners cry poor as tax deal splits industry", WA Today ( 2 July 2010) available at http://www.watoday.com.au/wanews/small-miners-cry-poor-as-tax-deal-splits-industry-20100702-zsa7.html (last visited 24 December 2012).
} 
particularly benefitted juniors whilst the new market value election benefits the larger miners more due to their greater investment bases. This partly explains why one of these juniors is proceeding with a Constitutional challenge to the new regime (with the endorsement of the mining States of Queensland and West Australia) notwithstanding its watering down. ${ }^{21}$

The closed door nature of the negotiations that were happening is also a concern. The justification was apparently that sensitive commercial information was being aired. Nevertheless this trend towards secrecy was maintained by the PTG in its deliberations on the details of the MRRT. The stakeholder consultation sessions were apparently not open to all stakeholders and of the 186 submissions received a mere 44 were made public of which few provided any considered rationale for the position they advanced. ${ }^{22}$ The PTG was also loaded with mining industry representatives ${ }^{23}$ with even the Federal Minister for Resources, Energy and Tourism, who was part of the Group, having been accused of being too close to the industry. ${ }^{24}$

The explanation for the substantial fall in the forward estimates is also a subject of contention. The industry maintains that it is due to a collapse in commodity prices and reflects a fall in mining profits. The Government has been reluctant to dispel this argument, not wishing to focus attention on the renegotiated features of its tax that may actually be the primary cause of the fall in revenues. Presumably these were taken into account in the revised 2010 Treasury figures although at least one senior Labor politician has publicly stated that the tax was not expected to raise any tax initially due to the availability of the massive deductions for capital, so bringing into question the veracity of the forward estimates. ${ }^{25}$

Additionally, possibly the market valuations performed by the miners in relation to the carried over assets have been particularly favorable providing them with enhanced deductions. There is also evidence to suggest that as the new rules do not catch value

${ }^{21}$ Clancy Yeates, "High Court threat to mining tax", Sydney Morning Herald (5 November 2012) available at http://www.smh.com.au/opinion/political-news/high-court-threat-to-mining-tax-20121105-28tw9.html (last visited 24 December 2012).

22 Diane Kraal and P.W. Senarath Yapa, "Resource rent taxes: the politics of legislation" (2012) 27 Australian Tax Forum 485 - 525.

${ }^{23}$ See http://www.alp.org.au/federal-government/news/policy-transition-group-membership-and-terms-ofre/ (last visited 26 December 2012). The former joint-chair of the PTG continues to promote mining company interests: Annabel Hepworth, "Mining leaders warn of exodus", The Australian (24 November 2012) available at http://www.theaustralian.com.au/business/markets/mining-leaders-warn-ofexodus/story-e6frg916-1226523110539 (last visited 26 December 2012).

${ }^{24}$ Phillip Coorey, "Oakeshott outraged by minister's legal threat", Sydney Morning Herald (3 November 2012) available at http://www.smh.com.au/opinion/political-news/oakeshott-outraged-by-ministers-legalthreat-20121102-28pgz.html (last visited 26 December 2012).

${ }^{25}$ See the comments ascribed to Simon Crean in "Mining tax fails to raise any revenue in first three months", News Limited Network (25 October 2012) available at

http://www.news.com.au/business/companies/mining-tax-fails-to-raise-any-revenue-in-first-threemonths/story-fnda1bsz-1226502856657 (last visited 24 December 2012). 
added by the miners and only the value of the resource there is an opportunity to (re)allocate value post the taxing point. ${ }^{26}$

However, of greatest concern to the potential revenue stream is the failure to place a cap on the availability of a tax credit to be offset against the MRRT for the payment of State based royalties. This has enabled State Governments to threaten to increase their royalties and gouge out the tax, resulting in promises from the Federal Treasurer to adjust transfer payments to the States in response. The Greens, independents and the Government's own review panel have all urged for amendments to the legislation to impose a cap. ${ }^{27}$ The subject has seen heated debate by politicians both within and outside Parliament, even to the extent of claims of defamation. ${ }^{28}$ The issue needs to be promptly dealt with as the parallel operation of the MRRT and the royalty regimes not only imposes additional administrative obligations on the industry but will continue as a source of dispute between the two tiers of Government. ${ }^{29}$

\section{The Carbon Tax}

\section{Climate change - the world on the edge}

If the scientists are correct our World is on the edge of a precipice brought about by climate change. Every country, indeed, humanity faces an uncertain future. ${ }^{30}$

For Australia, already the driest inhabited continent on Earth, ${ }^{31}$ the implications of global warming and the extreme weather forecasts are frightening. Whilst the important primary production industry has an uncertain future in the face of changing weather

${ }^{26}$ David Uren, "\$1.5bn MRRT tax shortfall sinks surplus hope" (5 November 2012) The Australian available at http://www.theaustralian.com.au/national-affairs/treasury/bn-mrrt-tax-shortfall-sinks-surplushope/story-fn59nsif-1226510236588 (last visited 24 December 2012).

${ }^{27}$ Lauren Wilson and David Uren, "Remove royalty credits from mining tax: troika", The Australian (1 December 2012) available at http://www.theaustralian.com.au/national-affairs/remove-royalty-creditsfrom-mining-tax-troika/story-fn59niix-1226527784804 (last visited 26 December 2012).

${ }^{28}$ Phillip Coorey, "Oakeshott outraged by minister's legal threat", Sydney Morning Herald (3 November 2012) available at http://www.smh.com.au/opinion/political-news/oakeshott-outraged-by-ministers-legalthreat-20121102-28pgz.html (last visited 26 December 2012).

${ }^{29}$ For media reports on this issue by Phillip Coorey: "Greens, MP want mining tax toughened", Sydney Morning Herald (26 October 2012) available at http://www.smh.com.au/opinion/political-news/greens-mpwant-mining-tax-toughened-20121025-2886y.html ; "Oakeshott wants Treasury brief on mining tax", Sydney Morning Herald (8 November 2012) available at http://www.smh.com.au/opinion/politicalnews/oakeshott-wants-treasury-brief-on-mining-tax-20121107-28yi3.html; "Unsustainable mining tax must be fixed - Oakeshott" (21 November 2012), Sydney Morning Herald available at http://www.smh.com.au/opinion/political-news/unsustainable-mining-tax-must-be-fixed--oakeshott-

20121120-29o2e.html and (with Mathew Dunckley) "Stand-off with states over mining royalties", The Australian Financial Review (18 December 2012) available at

http://www.afr.com/p/national/stand off with states over mining h2cyCYhG2QcOgZmrwNDu0M (all last visited 24 December 2012).

${ }^{30}$ It is not proposed to canvass the scientific debate in this paper. This has been performed admirably by others. For example, see Lidia Xynas, "Climate change mitigation: carbon tax - is it the better answer for Australia?" Australian Tax Forum 26 (2011): 339 - 347.

${ }^{31}$ See http://www.about-australia.com/facts/ (last visited 11 November 2012). 
patterns ${ }^{32}$ with $85 \%$ of the population coastal dwellers, ${ }^{33}$ rising sea levels will directly affect much of the population. The anticipated destruction of Great Barrier Reef before the end of the century and erosion of the country's World renowned beaches will impact harshly on tourism and the cherished quality of life of the Australian population. Apart from those island nations that will simply cease to exist ${ }^{34}$ few countries may be as adversely impacted by climate change as Australia.

It could, therefore, be anticipated that Australia would be at the forefront of efforts to reduce manmade emissions of carbon considered by most scientists to be cause of the problem that is climate change. However, huge distances between population centres, necessitating long distant transport, together with sprawling cities, have conspired to render Australia the greatest emitter of carbon per head of population in the developed World. ${ }^{35}$ Furthermore, its vast reserves of coal, and the vital extractive industry that these reserves support, provide no incentive to see the use of coal reduced, albeit that coal powered electrical generation is one of the World's primary sources of manmade carbon emissions. ${ }^{36}$

So the country has faced a conundrum. The quality of life of its inhabitants demands that climate change be tackled. Yet any measures focused on the reduction of carbon emissions will require both fundamental changes to the economy and to the entrenched behavior of the population. Furthermore, as a relatively small country in terms of population the impact of any carbon emission reductions in the global context might be almost negligible ${ }^{37}$ yet as a price taker in global markets its industry needs to remain competitive.

Apart from (initial) contention over the science and reality of human induced climate change it is these considerations that have been at the heart of the debate in Australia as to the appropriate response to global warming.

${ }^{32}$ B. L. Preston and R. N. Jones, Climate change impacts on Australia and the benefits of early action to reduce global greenhouse gas emissions, CSIRO February 2006 available at http://www.csiro.au/files/files/p6fy.pdf (last visited 11 November 2012).

${ }^{33}$ The Commonwealth of Australia, Australian Bureau of Statistics, Year book of Australia 2004 available at

http://www.abs.gov.au/ausstats/abs@.nsf/Previousproducts/1301.0Feature\%20Article32004?opendocum ent\&tabname $=$ Summary\&prodno $=1301.0$ \&issue $=2004 \&$ num $=\& v i e w=$ (last visited 11 November 2012).

${ }^{34}$ For example, see Bill Blakemore, "Micronesia: A third kind of Nation, Written off?", $A B C$ News, 9 December 2009 available at http://abcnews.go.com/Technology/global-warming-micronesia-islandnations-threatened-sea-level/story?id=9280340 (last visited 11 November 2012).

${ }^{35}$ Climate Commission, The critical decade: international action on climate change, Commonwealth of Australia 2012 available at www.climatecommission.gov.au (last visited 5 October 2012) 13 - 19.

${ }^{36}$ Coal amounts for around $75 \%$ of Australia's electricity generations: Climate Commission, The critical decade, 15.

${ }^{37}$ Although, according to the Climate Commission, Australia is the $15^{\text {th }}$ largest emitter (larger than around 180 other countries): Climate Commission, The critical decade, 14. 


\section{Australia's path to a price on carbon}

International agreement on climate change dates back to the early 1990s. In Rio de Janeiro, Brazil in 1992, 166 countries signed the United Nations Framework Convention on Climate Change ("UNFCCC") agreeing to work towards stabilizing greenhouse gas concentrations in the atmosphere. ${ }^{38}$ This Convention set no mandatory limits but in December 1997 the parties adopted the Kyoto Protocol, under which developed countries collectively committed to reduce greenhouse gas emissions by at least $5 \%$ below 1990 levels during 2008 to 2012.

Working alongside the Kyoto Protocol have been the United Nations climate change conferences. Since the 2010 session at Cancun (Mexico) though, countries have begun pledging to limit or reduce their emissions. These countries include Australia which has pledged to reduce its emissions by $5 \%$ compared with 2000 levels by $2020 .{ }^{39}$ Whilst it is difficult to compare the various pledges, Australia's Climate Commission has suggested that Australia's commitment is broadly comparable to other countries, in particular the targets of the United States, Japan, Europe and China. ${ }^{40}$

2007 is year zero for climate change response in Australia. As at the start of the year the Liberal coalition Government had been in power for just over 10 years during which time it had refused to ratify the Kyoto Protocol or establish a comprehensive greenhouse gas reduction strategy. Finally, following the final report of the Prime Ministerial Task Group on Emissions Trading, all but the diehards in the Government accepted the science of climate change and the Government committed the country to a carbon trading scheme. ${ }^{41}$ The Labor Opposition had also commissioned the Garnaut Climate Change Review earlier in the year. ${ }^{42}$ The result was that both major parties went to the November 2007 election with a promise to introduce carbon trading.

The subsequent election of a Labor Government was viewed as a mandate from the people to deal with climate change, which the new Prime Minister had said was the "greatest moral challenge" facing the country on which he was committed to act. Indeed one of the Government's first acts was to ratify the Kyoto Protocol. In the euphoria of the moment the introduction of a carbon price in Australia seemed assured.

\footnotetext{
${ }^{38}$ www.unfccc.int (last visited 5 October 2012). There were 195 signatories as at that date.

39 Australia is prepared to adopt a target of $25 \%$ reductions under strict conditions relating to significant global action.

${ }^{40}$ Climate Commission, The critical decade, 28.

${ }^{41}$ Available at http://pandora.nla.gov.au/tep/72614 (last visited 5 October 2012).

42 The 2008 report and 2011 update can be found at: http://www.garnautreview.org.au/ (last visited 5 October 2012). Garnaut supports an ETS over a carbon tax provided that it is not too heavily compromised.
} 
There followed during 2008 a number of reports and Government papers teasing out the details of how an ETS might be implemented and seeking community input. ${ }^{43}$ This fostered considerable public debate and political lobbying which extended throughout 2009. The Government faced the difficulty that, although it had a large majority in the lower house, the peculiarities of the Australian federal electoral system were that conservatives continued to control the Senate. Thus it was necessary for it to negotiate to ensure passage of its legislation. Against this political reality the Government introduced a Bill into Parliament on May 14, 2009 to enact an emissions trading scheme termed the "carbon pollution reduction scheme" ("CPRS"). ${ }^{44}$

However as a negotiated compromise the scheme failed to meet the expectations of environmentalists nor be acceptable to industry. There were too many exclusions, free permits and a particular problematic feature allowing for the acquisition of cheap permits from the developing World as a substitution for emission cuts. Furthermore, uncertainties remained and the complexity of the regime made it difficult to sell to the community. A foreshadowed low fixed permit price of $\$ 10$ AUD per tonne in the first year of operation raised the spectra that the scheme would create a mere revenue churn that would not be effective in achieving its environmental objectives.

Nevertheless, successful negotiations with the leader of the Liberal coalition in November 2009 seemed to ensure the safe passage of the Bill. However the inability of the Opposition leader to bring the remaining climate change skeptics within his party onboard saw him imprudently issue an ultimatum leading to his ousting as leader. ${ }^{45} \mathrm{His}$

${ }^{43}$ Including the Garnaut Review, Carbon Pollution Reduction Scheme, Green Paper, Commonwealth of Australia, Department of Climate Change, 16 July 2008 available at

http://www.climatechange.gov.au/government/reduce/ /media/publications/cprs/greenpaper.pdf (last visited 5 October 2012), Australia's Low Pollution Future: The Economics of Climate Change Mitigation, Treasury and Carbon Pollution Reduction Scheme: Australia's low pollution future, White Paper, Commonwealth of Australia, 15 December 2008 available at

http://pandora.nla.gov.au/pan/102841/20090728-

0000/www.climatechange.gov.au/whitepaper/report/index.html (last visited 5 October 2012).

${ }^{44}$ Issued first as an exposure draft for public consultation on 10 March 2009, then as a Bill on 14 May 2009

(see http://parlinfo.aph.gov.au/parllnfo/search/display/display.w3p;query=ld:legislation/billhome/R4127) which, following its failure to pass the Senate, was reintroduced in 2010 but subsequently lapsed upon Parliament rising for the calling of a general election (see

http://parlinfo.aph.gov.au/parllnfo/search/display/display.w3p;query=ld:legislation/billhome/R4281).

${ }^{45}$ In December 2009 Malcolm Turnbull was replaced by Tony Abbott after the former had instructed his colleagues that they should support the Government's emission trading proposal. See: Matthew Franklin, "Malcolm Turnbull sharpens the knife" The Australian (November 26, 2009) available at http://www.theaustralian.com.au/politics/malccolm-turnbull-sharpens-the-knife/story-e6frgczf1225803954519 (last visited 5 October 2012) and "Shock win for Abbott in leadership vote" ABC News (1 December 2009) http://www.abc.net.au/news/2009-12-01/shock-win-for-abbott-in-leadershipvote/1163910 (last visited 5 October 2012). 
replacement, a climate change skeptic himself, led the Senate to reject the Bill for a second time. ${ }^{46}$

Whilst the Bill was reintroduced into Parliament in 2010, public weariness of the issue together with an increasing reluctance to embark on any initiative whose impact on the economy was potentially negative at a time of continuing global economic instability, induced the Prime Minister to announce that resolution of the country's greatest moral challenge would be deferred until such time as greater World consensus was reached. ${ }^{47}$ His subsequent inability to achieve passage of the equally controversial mining tax was to see him replaced as leader in June 2010. Reading the community's fatigue with the issue his successor, Prime Minister Gillard, went to the August election under a no carbon tax platform. ${ }^{48}$ With the Opposition leader publicly doubting the science of climate change both major Australian political parties had dramatically retreated from a policy to impose a price on carbon in three short years. A highly popular Prime Minister and well regarded leader of the Liberal coalition Opposition had been dethroned in the process.

Nevertheless, a massive swing against the Government was to see it only retain office with the help of independents and the Greens as part of a power sharing agreement. This was a game changer. Carbon pricing was back on the agenda.

\section{The 2012 Australian ETS}

In fulfillment of the Labor Government's power sharing agreement with the Greens a Multi-party Climate Change Committee was established to determine the exact way this would be delivered. Fundamental design issues had to be negotiated in a highly charged atmosphere. Business and right wing lobby groups were fuelling the Opposition attacks. ${ }^{49}$ Pledges in blood that the regime would be repealed when they were returned to office, ${ }^{50}$ calls for a national plebiscite on its introduction ${ }^{51}$ and attempts to arrest

${ }^{46}$ On 2 December 2009.

${ }^{47}$ Announced 27 April 2010. See "Carbon Pollution Reduction Scheme" (Press release), Australian Government Department of Climate Change and Energy, 5 May 2010 available at www.climatechange.gov.au/en/media/whats-new/cprs-delayed.aspx (last visited 5 October 2012).

${ }^{48}$ Although the Government argues that an ETS was not ruled out. The difficulty is that these semantics seem to have been lost on the Australian population who generally believe that the Prime Minister was not truthful with them: see, for example, D. Atkins, "Carbon tax plan is do or die for Prime Minister Julia Gillard" The Courier-Mail (11 July 2011) available at www.couriermail.com.au/spike/columnists/carbontax-plan-is-do-or-die-for-prime-minister-julia-gillard/story-e6frerff-1226091892661 (last visited 5 October 2012).

49 See for example the criticism referred to in Randall Jackson, "Gillard announces carbon tax" Tax Notes International 61 (March 7, 2011): 729. However it should be acknowledged that some business leaders actually welcomed the introduction of a carbon tax preferring to see Australia not fall behind the rest of the world and encouraged by the end to the uncertainty it would bring: Randall Jackson, "Australian mining giant calls for carbon tax" Tax Notes International 59 (Sept 27, 2010): 1002.

${ }^{50}$ Randall Jackson, "Australia. Lower house passes carbon tax bills" Tax Notes International 65 (October 17, 2011): 177. 
power from the Government in the lower house ${ }^{52}$ were all part of the attack. On the other side, environmental lobby groups were demanding a price that internalized the full cost of carbon pollution and an end to contradictory policies (such as assistance to polluting industries).$^{53}$ Even actors ${ }^{54}$ and State politicians ${ }^{55}$ entered into the fray.

The Government's primary mechanism for galvanizing community support and introducing credible evidence to support its policy was to establish, as part of the Department of Climate Change and Energy Efficiency, a Climate Commission empowered to lead the national debate on the implications of climate change and the appropriate response. As at August 2012 the Commission had been very active, having issued 12 reports, primarily focusing on the need for strong rapid action and the steps Australia could take.

In February 2011 the Prime Minister announced the broad features of a resurrected ETS based on the recommendations of the Multi-party committee. ${ }^{56}$ However the precise details remained fluid with further refinement present in the draft legislative package issued for comment in July 2011 and the subsequent bills presented to

${ }^{51}$ Kristen A. Parillo, "Opposition leader seeks plebiscite on carbon tax" Tax Notes International 62 (June 27, 2011): 1011.

${ }^{52}$ Power is split 76/74 with the Government required to provide a speaker. One Government member has been facing possible criminal charges which have presented the possibility that he might need to vacate his seat. The support of the Independents has also not always guaranteed. An attempt by the Government to improve their position by persuading one of the Opposition members to be speaker backfired when allegations of improper behavior forced that member to step down and the Government was required to provide a speaker from its own ranks.

${ }^{53}$ David D. Stewart, "Think tank calls for coherent climate change tax policies" Tax Notes International 61 (February 21, 2011): 553.

${ }_{54}$ Randall Jackson, "Cate Blanchett panned for promoting carbon tax" Tax Notes International 62 (June 6, 2011): 763.

${ }^{55}$ See for example the threat by the New South Wales Treasurer to increase the state mining royalty tax (which increase would be reimbursed to the mining companies by the Federal Government in his view) to offset the effect of the carbon tax: Kristen A. Parillo, "Australian Feds, State tussle over mining tax" Tax Notes International 64 (Sept 12, 2011): 779.

${ }_{56}$ See the press release and attachments at http://www.pm.gov.au/press-office/climate-changeframework-announced (last visited 11 November 2012). 
Parliament in September $2011,{ }^{57}$ with even further changes made leading up to the 1 July 2012 commencement of the scheme. ${ }^{58}$

\section{The politics of implementation: price setting, exclusions and compensation}

The regime is the product of a political bargain. How some of the fundamental aspects of the regime were arrived can be explained as follows.

\section{Carbon tax or emissions trading scheme}

There is a debate as to the most appropriate mechanism for pricing carbon. Essentially there are two choices: a tax on carbon emissions or a market mechanism whereby a cap is placed on the amount of carbon that the country should emit and permits to emit carbon are issued and traded. Under such a "cap and trade" system permits might be

both issued by the Government and, effectively, created by entities trapping carbon. ${ }^{59}$

The Australian regime is a hybrid. This reflects a view that the country needs to be part of a global market for carbon permits that the Government hopes will exist by 2015. Until then the regime operates as a carbon tax which avoids the potential for price volatility in the carbon price. This has plagued the European Union ETS with the carbon price at one time falling dramatically when the market reacted to a view that there had been an oversupply of free permits. Price volatility was also especially a risk in the short term while the scheme remained the subject of controversy and threats to repeal it.

\footnotetext{
${ }^{57}$ The legislative package included four main bills: The Clean Energy Bill 2011 (which set up the carbon price mechanism); The Clean Energy Regulator Bill 2011 (which established a regulatory body to administer the mechanism); The Climate Change Authority Bill 2011 (which established a new Authority to advise the Government on the future design of the carbon price mechanism) and The Clean Energy (Consequential Amendments) Bill 2011. Generally see http://www.climatechange.gov.au/media/whatsnew/clean-energy-legislative-package.aspx (last visited 11 November 2012). Also see the Government's comprehensive plan Securing a clean energy future: the Australian Government's climate change plan issued in July 2011 and available at http://www.pm.gov.au/press-office/securing-clean-engergy-futureaustralia (last visited 11 November 2012). The Government maintains a website to promote its plan and keep the community abreast of developments: www.cleanenergyfuture.gov.au (last visited 11 November 2012).

${ }^{58}$ For example, see the Clean Energy Legislation Amendment Act 2012 available at http://www.comlaw.gov.au/Details/C2012A00084.

${ }^{59}$ The respective advantages and disadvantages of these alternative approaches have been the subject of much debate, one which it is not appropriate to engage in this paper. Suffice to say that a major deficiency in the carbon tax approach is the lack of a cap - conceivably the amount of carbon emissions could stay the same or even rise with the added cost simply passed on to consumers. The setting of the tax rate (ie. the carbon price) would also be problematic for governments. Too low and nothing is achieved. Too high and the economy might be significantly damaged. Whilst a market based "cap and trade" scheme avoids these limitations such regimes suffer from the unknown and complexity. The negative impact on investment planning arising from the uncertainty as to the future carbon price, difficulties in fairly allocating carbon credits and the potential for speculation and corrupt market practices also have the potential to derail their effectiveness. Lidia Xynas comprehensively canvasses the opposing arguments in relation to carbon taxes and emission trading schemes concluding that a carbon tax is preferable: Xynas, "Climate change mitigation: carbon tax - is it the better answer for Australia?", 352 370. For a similar conclusion see Jim Corkery, "A carbon tax - onwards" Revenue Law Journal 19(1) (2009): 1 - 8.
} 
Ensuring a minimum ceiling for the carbon price both has the effect of maintaining the impetus for behavioral change, especially by providing assurance to those contemplating low carbon investments, and protecting government revenues.

\section{The carbon price}

The hybrid nature of the regime required the Government to set the initial price. This exercise involved a tradeoff between the environment and the economy. It was inevitable that proponents of the two sides would be unsatisfied with the outcome. Business interests pointed to the price at which carbon permits were trading in Europe (around \$15 AUD) whilst environmentalists pointed to analysis that suggested a price around $\$ 130$ AUD was necessary to drive a move to renewable energy sources. Ultimately the price of $\$ 23$ AUD accepts a need for carbon to be priced but at a level that the Government hopes will not damage the economy and lead to massive carbon leakage.

\section{Large emitter threshold}

The regime applies to "large" emitters, namely entities that emit 25,000 metric tonnes ${ }^{60}$ of carbon dioxide annually (or the equivalent) ${ }^{61}$ with entities required to calculate emissions and be subject to audit. The Government has stated that this should account for around $60 \%$ of Australia's greenhouse gas emissions. The logic behind the threshold is to not burden smaller emitters with the cost and administration imposed by the regime, although those close to the threshold will still need to be able to verify that their emissions level does not exceed it. Notably the Clean Energy Regulator downgraded the list of affected entities from a projection of more than 500 (initially 1,000 ) to only 294 just prior to the regime taking effect. ${ }^{62}$

\section{Exemption for the agricultural sector}

The agricultural sector was exempted albeit that it is the country's third largest emitter. Various justifications for this have been given including the difficulty of measuring emissions on farms, ${ }^{63}$ the fact that the industry is a price taker and could not pass on the added $\operatorname{costs}^{64}$ and that the concession was necessary to obtain the support of the

\footnotetext{
${ }^{60}$ Some landfill operators emitting 10,000 tonnes or more and certain natural gas retailers are also caught. Entities may also elect to opt-in to the regime to avoid the payment of taxes such as the fuel excise. The scheme contains provisions directed at schemes splitting emissions over different entities in an attempt to fall below the threshold.

61 The ETS applies to four of the six greenhouse gases acknowledged in the Kyoto Protocol.

${ }^{62}$ Randall Jackson, "Fewer firms expected to pay carbon tax" 66 Tax Notes International 66 (June 25, 2012): 1193.

${ }^{63}$ Id.

${ }^{64}$ See the comments attributed to the National Farmers' Federation by Jackson, "Australian mining giant calls for carbon tax", 1002.
} 
independents on whom the Government relies. ${ }^{65}$ Gasoline was also exempted but large diesel and jet fuel users are to be subject to increases in excise taxes. ${ }^{66}$

Emissions intensive trade exposed ("EITE") industries

EITE industries are those on whom the imposition of a carbon price is particularly likely to damage their international competitiveness, such as steel, aluminum, zinc and glass production. Such industries might well respond by relocating to a jurisdiction that does not impose a price on carbon. This phenomenon is termed "carbon leakage". To mitigate this possibility such industries are to receive substantial assistance in the form of free units covering up to $94.5 \%$ of their liability during the first three years, although this assistance will taper off at $1.3 \%$ per annum reflecting a carbon productivity contribution. The steel industry is to receive added assistance to encourage innovation and efficiency whilst the natural gas industry is also to receive a special $50 \%$ assistance level. The coal sector is to receive special assistance to help the transition away from the most emissions intensive coal mines whilst an energy security fund is to be established to provide some assistance to the electricity generation sector. These aspects of the regime all reflect the Government's concern not to damage the economy with a too greater initial shock but rather to allow high emitting industries critical to the economic health of the nation time to introduce measures to reduce their exposure.

On the other side of the equation the Government is also supporting the nascent clean energy industry. The most significant proposal is the establishment of the Clean Energy Finance Corporation to be set up to increase investment in renewable energy, energy efficiency and other low emissions technology. The Government has been active to promote the opportunities that the introduction of the scheme has for those wishing to be part of the vanguard of a new clean energy industry.

The level of assistance to EITE industries is particularly controversial and problematic. Whilst the rationale is to encourage the continuation of domestic production and prevent carbon leakage it has been argued that the assistance is excessive leading to windfall gains to these industries, the damaging of the environmental effectiveness of the regime by reducing incentives and increasing the cost of carbon reduction elsewhere in the economy. ${ }^{67}$ This is not to say that properly designed assistance to EITE industries may not be appropriate and necessary. The alternative of a border adjustment tax on imports from non-carbon pricing jurisdictions suffers from legal uncertainty in terms of compliance with GATT principles, administrative costs and calculation difficulties and could lead to international trade disputes and protectionism. Until international agreement and acceptance of such a mechanism is achieved the approach adopted in

\footnotetext{
${ }^{65}$ Reported in Jackson, "Gillard announces carbon tax", 729.

${ }^{66}$ In the case of fuel for heavy road transport the exemption applies only for the first two years.

${ }^{67}$ T. Wood and T. Edis, New protectionism under carbon pricing: case studies of LNG, coal mining and steel sectors, The Grattan Institute 2011.
} 
Australia of a free allocation of units is likely to be the preferred approach to counter carbon leakage. ${ }^{68}$

\section{Compensation and managing price rises}

Whilst it was acknowledged, and indeed is the rationale for the scheme, that the price of certain products in the market place would rise, the Australian Competition and Consumer Commission ("ACCC") is to take action against any price gouging claimed falsely to be as a result of the introduction of the regime. Certainly it was anticipated that the price of electricity would rise but businesses intending on passing on additional costs to consumers are required to be able to substantiate that this is a result of the carbon measures if this is, in fact, what they claim. Given the potential for the electricity price rises to challenge the community's resolve to put a price on carbon ${ }^{69}$ the Government initiated a marketing offensive to defray concerns as to the significance of the carbon price on electricity prices: ${ }^{70}$ see figure 1.

Although there is contention over whether the initial set price of \$23 AUD a tonne is too low (to encourage a change in behavior or investment in clean energy) or too high (compared to other regimes and hence damaging the international competitiveness of Australian businesses) forecasts suggest that it will flow through as a $5-10 \%$ increase in the price of electricity and gas, $0.5-2 \%$ increase in the price of steel, aluminum and cement and $0-0.5 \%$ increase in the cost of waste removal services, water, fuel, chemicals and paper. ${ }^{71}$ These price rises are promoted by the Government as modest and more than offset by the increased compensation to some businesses and households. Whilst the Opposition suggests that the ETS and its counter veiling compensation measures will simply generate a pointless money churn the Government argues that cashed up households will spend their extra funds wisely focusing on those industries and products that are able to avoid price rises through clean energy investment and/or energy savings. Market forces will, therefore, accelerate the desired change in behavior.

Although the Opposition mounted a scare program in the lead up to 1 July $2012,{ }^{72}$ price monitoring in the months following identified little impact from the ETS. ${ }^{73}$ Admittedly

\footnotetext{
${ }^{68}$ Elena de Lemos and Pinto Aydos, "Australia's carbon pricing mechanism" in Carbon pricing, growth and the environment, Larry Kreiser, Ana Yabar Sterling, Y Pedro Herrera, Janet E Milne and Hope Ashiabor (eds) (Abingdon Oxon Edwards Elgar Publishing 2012): 261 - 276.

${ }^{69}$ Approximately $35 \%$ of Australia's carbon emissions come from the generation of electricity: Burgess, "Australia's carbon Sunday: a price is put on carbon emissions", 751.

70 The carbon price was estimated to add around \$300 AUD annually to household power bills: Jackson, "Gillard announces carbon tax", 729.

${ }^{71}$ Generally see: The Commonwealth of Australia, An overview of the clean energy package, available at http://www.cleanenergyfuture.gov.au/wp-content/uploads/2012/05/CEF-overview Apr2012.pdf (last visited 11 November 2012).

${ }^{72}$ Resulting in comedians and comics blaming the carbon pricing scheme on everything ranging from being late for work through to the poor performance of the Australian cricket team.
} 
these were early days and it might be expected that any flow on effect will take some time to work its way through to retail prices. There were, however, a number of grievous and well publicized attempts to profit gouge blaming the ETS identified by the ACCC. ${ }^{74}$ There were also businesses that were rumored to have sacked workers, closed down or moved offshore in response partly, at least, to the introduction of the measures with small business reportedly particularly affected due to their apparent inability to be able to pass on the additional costs arising from the carbon price. ${ }^{75}$

Presumably the Government hopes that the package as a whole sufficiently sugar coats the introduction of a carbon price so that both the economy (and the Government) can survive the experience. At the same time the measures must not be that unobtrusive that they do not bring about the desired behavioral change. Only time will tell although on 18 October the Government announced that carbon emissions from electricity generation had fallen since the introduction of the measures, although at the same time arguing that the carbon price had only marginally contributed to a rise in electricity prices. ${ }^{76}$ The Government is, it seems, having it both ways.

\section{Is there really an Australian carbon pricing spring and, if so, will it prevail?}

The lingering effects of the global economic crisis stymied the nascent attempts by some World leaders to rise above the disappointments of the Copenhagen, Cancun and Durban climate change conferences and actually implement a fiscal response to climate change. Australia has been a star exception, albeit that the country only contributes $1.5 \%$ of the global greenhouse gas emissions. ${ }^{77}$ This raises the question as to why has the country proceeded down a path so many other countries have shied away from?

The answer is one of political necessity. Notwithstanding the Prime Minister's noncarbon tax pledge, decimation at the 2010 polls saw the Government only retain power with the aid of the Greens on whose insistence the implementation of a carbon price became Government policy. Furthermore, it could be suggested that the regime is mere window dressing - an attempt to look as if the Government is doing something. Given

\footnotetext{
${ }^{73}$ David D. Stewart, "Carbon tax has little effect on consumers, report shows" Tax Notes International 67 (August 13, 2012): 611.

74 The managing-director of one of the country's largest bakery chains was forced to resign after a newsletter was leaked were he urged his franchises to put up prices and blame it on the carbon tax: Randall Jackson, "Head of bakery chain resigns over carbon tax deception" Tax Notes International 67 (July 16, 2012): 201. Also see Randall Jackson, "Government clarifies relationship between carbon tax, GST" Tax Notes International 67 (July 23, 2012): 305.

${ }^{75}$ Steve Lewis and Lisa Cornish, "Carbon price unfair to small businesses" The Daily Telegraph (August $20,2012)$ available at http://www.news.com.au/business/your-business/carbon-pain-registers-forbusinesses/story-fn9evb64-1226453653623 (last visited 5 October 2012).

${ }^{76}$ The Hon Greg Combet, "Evidence shows carbon price is working", Media Release GC 287/12, (18 October 2012).

${ }^{77}$ The Commonwealth of Australia, Securing a clean energy future: The Australian Government's climate change plan (AGPS 2011) 21 available at www.cleanenergyfuture.gov.au/wpcontent/uploads/2011/07/Consolidated-Final.pdf at p xi (last visited 5 October 2012).
} 
Treasury estimates that a price around $\$ 131$ AUD per tonne is necessary to meet the Government's greenhouse gas reduction targets, ${ }^{78}$ something politically inconceivable, it is difficult to see how a price of \$23 AUD per tonne will generate sufficient financial imperative to steer the economy towards a renewable energy future. If there is likely to be one real effect of the Government's climate change reforms it may be to lock the economy into an alternative fossil fuel, namely gas-fired power rather than the more polluting coal-fired power. ${ }^{79}$

The likelihood of the failure of the pricing to be able to achieve the outcome pleaded for by the scientists may be exacerbated by other design features ${ }^{80}$ Notable of these are the limited application of the tax to 294 big polluters (1,000 was the initial plan), ${ }^{81}$ the exclusions for some industries and sectors (notably agriculture), the free units for trade exposed high polluting entities (shielding them from up to $94.5 \%$ of their liability) and the massive household compensation scheme that will see nine out of ten households receiving some compensation, many in excess of the anticipated impact on them. ${ }^{82}$ The combined effect of these features is that the regime will not be revenue neutral for the Government, at least initially. Whilst the rationale of the compensation is to soften its introduction, the Government must surely be looking towards the long term. For carbon pricing to generate the necessary behavioral changes the compensation package must eventually disappear into the inflation generated bracket creep and government policy change morass. ${ }^{83}$

In any event, whether the Government's carbon pricing mechanism (for what it is) has a long term future is uncertain. Whilst the weight of the science has apparently convinced most in the Opposition that climate change is real and manmade, the centre piece of their climate change policy is direct measures at tackling carbon emissions with a promise to repeal the ETS. This threat to repeal the regime is significant given that the Opposition is expected to win the elections scheduled for late $2013 .{ }^{84}$ Even the mere threat is damaging enough to the policy aims of the regime. The Opposition has warned businesses not to purchase forward units in a scheme that will be closed down. Any investment decisions away from fossil fuels towards renewable energy need long term

\footnotetext{
${ }^{78}$ The Commonwealth of Australia, The Treasury, Strong Growth, Low Pollution: Modeling a carbon price (AGPS 2011) : 11, available at http://cache.treasury.gov.au/treasury/carbonpricemodelling/content/report/downloads/Modelling Report Consolidated.pdf? $\mathrm{v}=2$ (last visited 5 October 2012).

${ }^{79}$ See John Passant, "Australia's carbon tax - the sweet and the sour" Bulletin for International Taxation 65(12) (2011).

${ }^{80}$ For a similar sentiment see: Evgeny Guglyuvatyy, "Australia's carbon policy - a retreat from core principles" eJournal of Tax Research 10 (3) (2012): 552 - 572.

81 Jackson, "Fewer firms expected to pay carbon tax", 1193.

${ }^{82} \$ 10.10$ per week compensation for the average family as against an anticipated increase in costs of \$9.90: The Commonwealth of Australia, Securing a clean energy future: The Australian Government's climate change plan.

${ }^{83}$ Passant, "Australia's carbon tax - the sweet and the sour", 12.

${ }^{84}$ Australia must hold its next federal election by 30 November 2013.
} 
certainty and investment groups have slammed this approach of the Opposition as irresponsible and introducing political risk into the investment equation. ${ }^{85}$

Of course, whether the Opposition will be elected (and have control of both houses of Parliament) cannot be taken for granted, even given their current lead in the polls. ${ }^{86}$ The current Opposition leader is as unpopular as the Prime Minister and liable to damaging gaffs. ${ }^{87}$ Furthermore, whilst he has made a "pledge in blood" that he will repeal the regime ${ }^{88}$ the international implications of such a move now that an agreement for mutual recognition of European units has been forged, the fact that domestic businesses may have, in fact, bought units in advance and the need to also unwind the massive compensation arrangements directed towards business and households, would make this a challenging proposition.

\section{Conclusion}

The saga of the mining tax in Australia is a lesson in how vested interests can hijack Government policy and even turn the very people that the policy is designed to benefit against it. It is a story not just about the power of advertising and the media, political opportunism, the excessive influence of lobbyists and the rise in dominance of multinational corporations over the nation state. But, it is also a story about lost opportunities, the squandering of a nation's assets and a betrayal of future generations. Time will tell if the mining tax can be re-invented into something more effective ${ }^{89}$ or will even survive in its current state. ${ }^{90}$ Its greatest ally may be its weakness. As the community learns of the extent of the miner's victory perhaps the pendulum may swing in favour of strengthening the tax.

Whilst the Government continues to revise down its budget forecasts and ponder as to where it went wrong it may reflect on the need for strong leadership in dealing with

${ }^{85}$ David D. Stewart, "Australia. Investment groups praise carbon tax as opposition pledges repeal" Tax Notes International 65 (October 24, 2011): 254.

${ }^{86}$ The latest opinion polls suggest that Labor may be recovering ground: Peter Lewis and Jackie Woods "Polls apart: is Labor really coming back?" ABC The Drum Opinion (10 October 2012) available at http://www.abc.net.au/unleashed/4303712.html (last visited 12 November 2012).

${ }^{87}$ Phillip Coorey, "Turnbull firms as preferred leader" The Sydney Morning Herald (September 17, 2012) available at http://www.smh.com.au/opinion/political-news/turnbull-firms-as-preferred-leader-20120916260ki.html (last visited 12 November 2012).

${ }^{88}$ Whatever that means. Reported in Jackson, "Australia. Lower house passes carbon tax bills", 177.

${ }^{89}$ Hoped for by some: Peter Hannam, "Don't give up on mining tax, ex-banker says" Sydney Morning Herald (30 November 2012) available at http://www.smh.com.au/business/dont-give-up-on-mining-taxexbanker-says-20121129-2ainh.html (last visited 24 December 2012).

${ }_{90}$ The Construction Forestry Mining and Energy Union is running an advertising campaign directed at the leader of the Opposition's promise to repeal the tax insinuating that he is a lackey for the mining companies: Clay Lucas, "Qantas pulls union's mining ads" (29 November 2012) The Age available at http://www.theage.com.au/travel/travel-news/qantas-pulls-unions-mining-ads-20121129-2ahzg.html (last visited 24 December 2012). 
vested interests. Consultation on implementation is one thing but negotiation on considered Government policy should only be only permitted at the margins. A healthy skepticism to claims of impending doom should be entertained.

Perhaps the one positive legacy from the Australian fiasco is the precedent that has encouraged other countries, especially those in Africa, to seek a greater return for the nation from the exploitation of their non-renewable resources. Maybe the global race to the bottom in relation to mining taxation, a description that has typically been ascribed to the competition to lower taxes on multi-national companies or risk their relocation, might slow or even reverse.

The Australian carbon pricing mechanism is the product of ten years of heated political debate. It played a part in the demise of the country's second longest serving conservative Prime Minister who took too long to accept the science. It saw the end of a conservative Opposition leader who fell on his sword trying to drag the skeptics in his party to an enlightened future. It hastened the end of one of the most popular Prime Ministers in Australian history ${ }^{91}$ who, after campaigning on a climate change response being the greatest moral challenge facing the country, failed in his attempts to pass the legislation. It witnessed his successor campaign on the promise that no carbon tax would be introduced then, within six months, announce that the Government would proceed to introduce an ETS. Even now, with the regime operating, it remains controversial and its future uncertain. ${ }^{92}$ Furthermore, there is a concern that the political concessions necessary to achieve its introduction may have watered the regime down to such an extent that it will be ineffective to achieve its environmental objectives.

Whilst political economy theory predicts that broad ranging ETSs are almost impossible to introduce as the most influential political actors oppose carbon markets, the Australian experience bears out that under certain circumstances policy windows for the introduction of such systems may open. ${ }^{93}$ However this opening may well have been the result of serendipity that could be short-lived.

\footnotetext{
${ }^{91}$ Second in ranking with a popularity rating of $74 \%$ : see "The Rudd Supremacy" (March 30, 2009) available at http://www.brisbanetimes.com.au/national/the-rudd-supremacy-20090330-9g6s.html (last visited 6 November 2012).

${ }^{92}$ As at October 2012 debate still rages in the media between the Government and anti-ETS proponents: for example see: The Hon Greg Combet, "Dick Warburton's inaccurate claims", Media Statement GC 292/12, 25 October 2012 available at http://www.climatechange.gov.au/ /media/Files/minister/combet/2012/media/october/CombetMediaRelease-292-12.pdf (last visited 13 November 2012).

${ }^{93}$ Discussed and referenced in the paper by Sven Rudolph and Takeshi, "Tokyo's greenhouse gas emissions trading scheme: a model for sustainable megacity carbon markets?" available at http://ideas.repec.org/p/mar/magkse/201225.html (last visited 13 November 2012).
} 


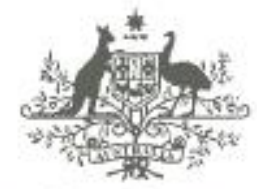

Australian Government

\section{Where every $\$ 100$ on your electricity bill goes}

The carbon price will cut pollution and drive investment in clean energy like solar and wind power.

\section{$\$ 9$}

Corbon price:
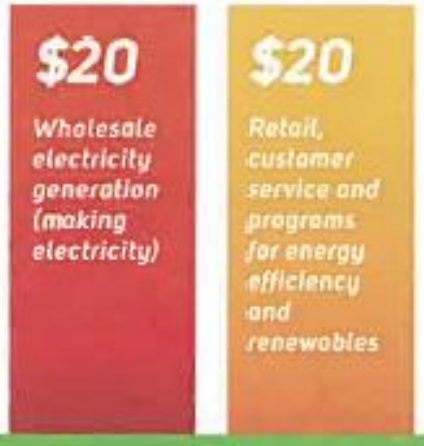

Nationalaverage figures provided by the Commonwealth Treasury. These figures include GST. Individual bills will depend on a number of factors including your household consumption, metering type and where you tive 